\title{
The Effect of Mesenchymal Secretome Stem Cell Therapy toward Caspase-3 Expression in Pregnant Mice with Pristan-Induced Lupus Model
}

\author{
Febrian Andhika Adiyana, M. Adrianes Bachnas, Sri Sulistyowati, \\ Nutria Widya Purna Anggraini, Supriyadi Hari Respati
}

\begin{abstract}
Department of Obstetrics and Gynecology, Faculty of Medicine, Universitas Sebelas Maret/ Dr. Moewardi Hospital, Surakarta
\end{abstract}

\section{ABSTRACT}

Background: Systemic lupus erythematosus (SLE) is one of the pregnancy complications which cause an increase in fetal and maternal complications which are mainly caused by placental damage due to chronic inflammation and apoptosis. The rate of apoptosis can be assessed by the high expression of caspase- 3 which is the majorexecutioner caspases of apoptosis. The use of Mesenchymal Secretome Stem Cell for SLE therapy has an anti-inflammatory and anti-apoptotic role. This study aimed to examine the effect of mesenchymal secretome stem cell therapy toward caspase- 3 expression in pregnant mice with pristan-induced lupus model.

Subjects and Method: This study was a randomized controlled trial. This study was conducted at the Prodia ProStem Laboratory, Laboratory of the Faculty of Veterinary Medicine of Airlangga University, and Anatomical Pathology Laboratory, Faculty of Medicine, Airlangga University. A total of 14 healthy BALB/C female mice strain aged 6-8 weeks, with a bodyweight of 20-30 grams, were divided into two groups, (1) 7 pregnant mice who received pristan therapy only, and (2) 7 pregnant mice who received pristan therapy and mesenchymal secretome stem cell.
The dependent variable was the caspase-3 expression. The independent variable was the administration of mesenchymal secretome stem cell therapy. The caspase- 3 expression was measured by an immunoreactive score. The data were analyzed using independent t-test.

Results: After giving mesenchymal secretome stem cell therapy, the mean of the caspase- 3 expression in the treatment group (Mean=1.86; $\mathrm{SD}=-$ o.66) was lower than the control group (Mean=3.30 ; $\mathrm{SD}=1.42$ ), with $\mathrm{p}=0.031$.

Conclusion: Mesenchymal secretome stem cell therapy is effective for reducing caspase-3 expression in the placenta of pregnant mice with pristan-induced lupus model.

Keywords: Caspase- 3 expression, lupus, placenta

\section{Correspondence:}

Febrian Andhika Adiyana. Department of Obstetrics and Gynecology, Faculty of Medicine, Universitas Sebelas Maret/Moewardi Surakarta, Indonesia. Email: FebrianAndhika@gmail.com. Hp: 081215897960.

\section{Cite this as:}

Adiyana FA, Bachnas MA, Sulistyowati S, Anggraini NWP, Respati SH (2020). The Effect of Mesenchymal Secretome Stem Cell Therapy toward Caspase-3 Expression in Pregnant Mice with Pristan-Induced Lupus Model. Indones J Med. 05(03): 224-229. https://doi.org/10.26911/theijmed.2020.05.03.07.

cc) (F) (-) Indonesian Journal of Medicine is licensed under a Creative Commons EY NG SA Attribution-Non Commercial-Share Alike 4.o International License.

\section{BACKGROUND}

Systemic lupus erythematosus (SLE) is commonly found in adolescent girls and women of reproductive age, with a peak incidence at the age of 15-45 years (Khurana and Wolf, 2017; Ling et al., 2018). Lupus is one of the pregnancy complications of which causes an increase in fetal and maternal complications which are mainly caused by placental damage due to chronic inflammation and apoptosis (Ling et al., 2018). The increase of apoptosis in villous trophoblast was found in pathologi- 
cal conditions in the placenta, including preeclampsia, IUGR (intra uterine growth retardation), gestational trophoblast disease, and systemic diseases such as diabetes and maternal SLE. Apoptosis was suspected to play an important role in the mechanism of placental dysfunction (Sharp et al., 2010). Aspase- 3 was a protease that was often activated in apoptosis of mammalian cells, thus considering to be the main executioner of the apoptotic process (Dos Santos et al., 2017).

The use of corticosteroids and cyclophosphamide as immunosuppressive therapy in SLE has been used extensively. However, they have significant side effects. Mesenchymal secretome stem cell was the greatest type of stem cells to be the cell-based therapy for inflammatory diseases (Harrell et al., 2019). Mesenchymal secretome stem cell was the result of stem cell secretions that contain growth factors, chemokines, cytokines, metabolites, and bioactive lipids (Drago et al., 2013). Some of the mesenchymal secretome stem cell metabolites which have this ability are HGF and TGF- $\beta$. Both of these mediators have anti-apoptotic and anti-inflammatory abilities (Teixeira, 2017). This study aimed to determine the effect of mesenchymal secretome stem cell therapy toward lupus in pregnancy. It was assessed from the expression of caspase- 3 in the placenta as a representation of excessive apoptosis.

\section{SUBJECTS AND METHOD}

\section{Study Design}

This study was a randomized controlled trial with single blind. This study was conducted at the Laboratory of the Faculty of Veterinary Medicine and the Anatomical Pathology Laboratory of the Faculty of Veterinary Medicine, Airlangga University.

\section{Population dan Sample}

A total of 14 healthy BALB/C female mice strain aged 6-8 weeks, with a body weight of 20-30 grams, were prepared at the Labora- tory of the Faculty of Veterinary Medicine, Airlangga University. The criteria of the healthy mice were as follows: the mice had shiny eyes, the fur was not dull, active, and good appetite. Mice classification was divided into two study groups, namely the control group who received injection of pristan without secretome and the treatment group who received injection of pristan and secretome. Pristan injection was used to induce lupus in mice. Mice that failed to induce lupus with pristan, failed to synchronize lust, failed to get pregnant, died, or delivered preterm were excluded from the sample of this study.

\section{Study Variables}

The dependent variable was the caspase- 3 expression. The independent variable was the mesenchymal secretome stem cell.

\section{Operational Definition of Variables} Mesenchymal secretome stem cell was the result of the secretion of mesenchymal stem cell obtained from Wharton's Jelly of the umbilical cord of infants that were born normally through sectio caesarea surgery cultured under hypoxic conditions on standard media.

Caspase-3 expression was an indicator of the apoptotic process determined by the brown color on immunohistochemical examination and assessed with an immunoreactive score

\section{Study Instruments}

The phenotype of lupus in mice was induced using intraperitoneal pristan injection. Caspase-3 expression was obtained from the sample of mice placental tissue on the 16th day of pregnancy. Immunohistochemical examination was carried out on the sample using a monoclonal antibody of Bioss Caspase-3 Monoclonal Antibody serial number bs-oo81R. Mesenchymal secretome stem cells were obtained from Wharton's Jelly of umbilical cord of infants that were born normally through sectio caesarea surgery cultured under hypoxic conditions on standard media. 
Adiyana et al./ The Effect of Mesenchymal Secretome Stem Cell Therapy

\section{Data Analysis}

The mean differences of caspase-3 expression in the control and treatment groups were analyzed using t-test.

\section{Research Ethics}

The study ethics included informed consent and ethical clearance. The eligibility of this study was obtained from the Ethics Committee of the Faculty of Veterinary Medicine, Airlangga University, Surabaya, East Java, Indonesia, Number 3.KE.167.10.2018.

\section{RESULTS}

This study engaged 14 pregnant mice with pristan-induced lupus model. The 7 pregnant mice were in the treatment group and received mesenchymal secretome stem cell therapy. 7 other micewere in the control group. The researchers did not conduct initial measurements toward the laboratory animals. They were considered to have the same initial value because they came from one controlled population.

Table 1. The comparison of caspase-3 expression in the control and treatment groups

\begin{tabular}{ccccc}
\hline Group & $\mathbf{n}$ & Mean & SD & p \\
\hline Control & 7 & 3.30 & 1.42 & 0.031 \\
Treatment & 7 & 1.86 & 0.66 & \\
\hline
\end{tabular}

Table 1 shows the comparison of caspase- 3 expression in the control group and the treatment group. Table 1 shows that the mean of the caspase- 3 expression in the treatment group (mean=1.86; $\mathrm{SD}=0.66)$ was lower than the control group (mean=3.30; $\mathrm{SD}=1.42$ ), with $\mathrm{p}=0.031$.

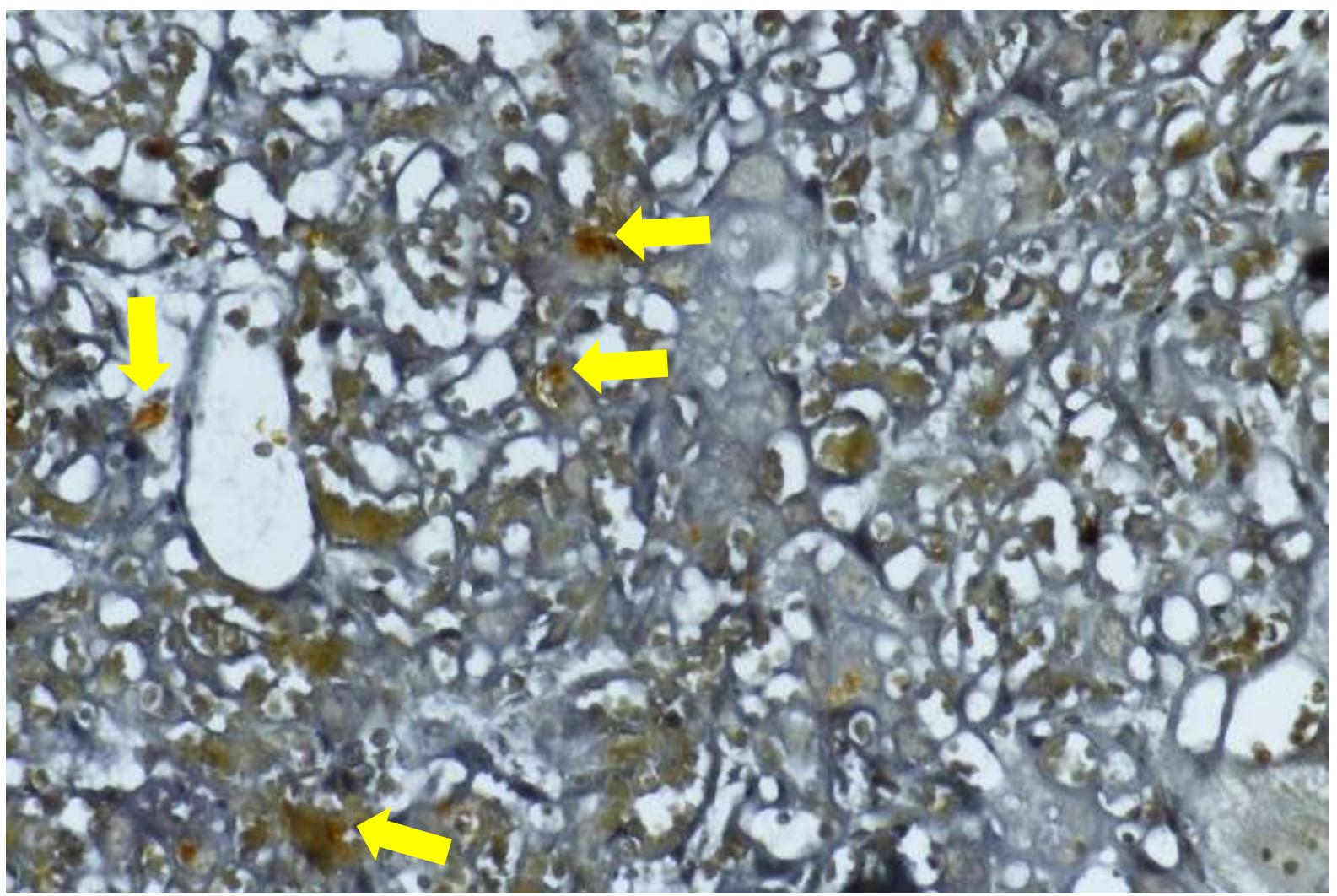

Figure 1. The caspase-3 expression in the placenta of the control group 


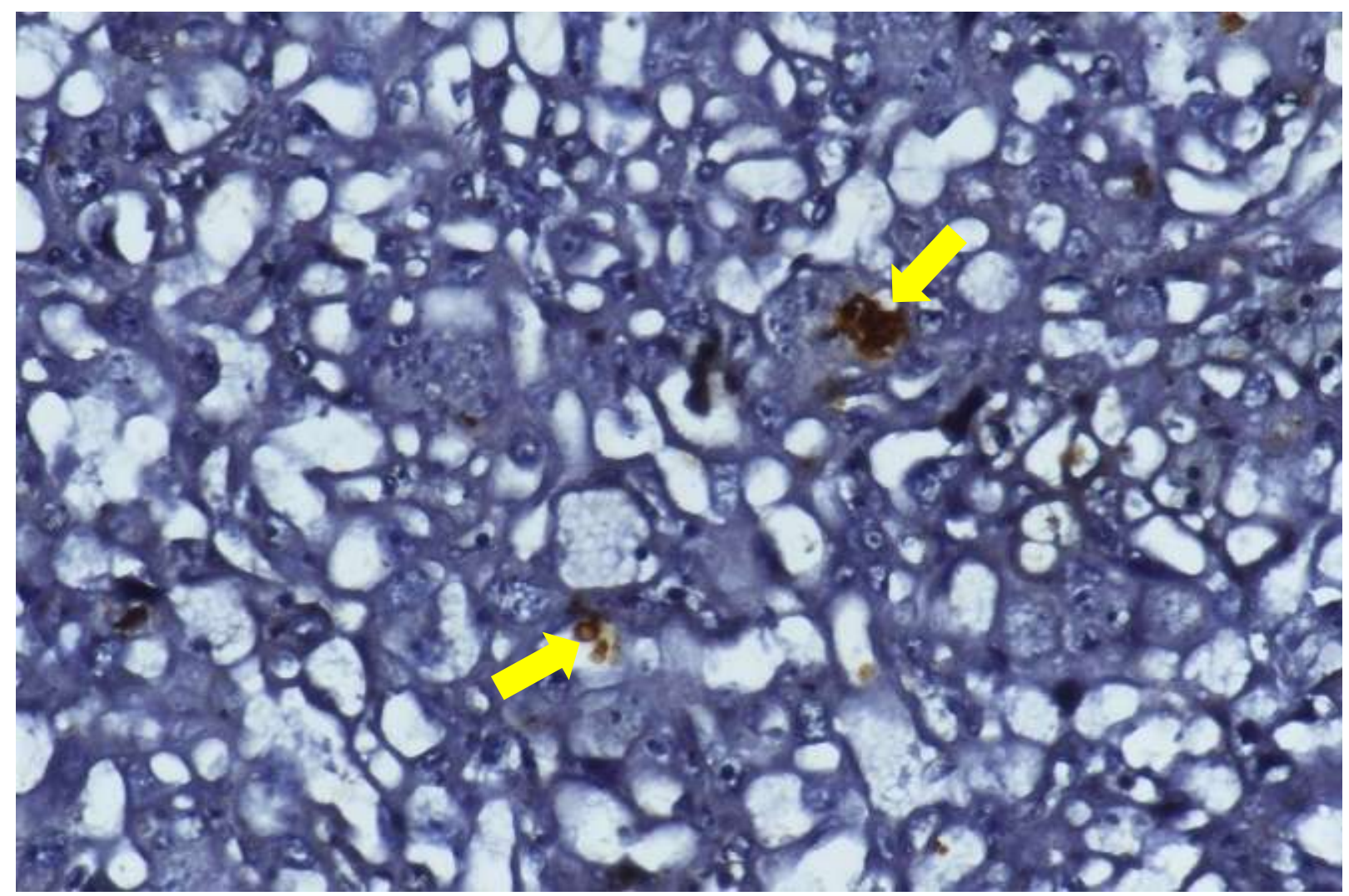

Figure 2. The caspase-3 expression in the placenta of the treatment group

\begin{abstract}
Systemic lupus erythematosus (SLE) is a chronic autoimmune inflammatory disease which basically comes from apoptotic disorders and disruption of cell cleansing ( $\mathrm{Su}$ et al., 2014). Lupus is one of thepregnancy complications, where there were 1-2 cases of SLE in every 2000 pregnancies (Prawirohardjo, 2014). It was found that LES could cause maternal and fetus complications that mainly occurred due to placental damage. It occurred due to chronic inflammation in SLE patients. One indicationthat caused placental damage was increased apoptosis, which could be shown by increased caspase-3 expression as the major executioner of apoptosis (Ogishima, 2000).

Mesenchymal secretome stem cell was known to have anti-apoptotic and antiinflammatory abilities. Some of the mesenchymal secretome stem cell metabolites
\end{abstract}

which have this ability are HGF and TGF- $\beta$ (Teixeira, 2017).

The stem cell secretomecould affect maturation, migration, polarization, and macrophage function through the production of various chemokines, thus suspecting to improve immune response and reduce chronic inflammation in patients with SLE (Lin and $\mathrm{Du}, 2018$ ). The use of mesenchymal secretome stem cell in SLE therapy could inhibit activation and proliferation of autoreactive lymphocytes, as well as increase production of pro-inflammatory cytokines. This suppressive effect was caused by improved function and activity of Treg cells and decreased Th17 cell levels (Figueora et al., 2014). With the decrease in IL-17 levels produced by Th17 cells, Treg activity, in regulating the appearance of antibodies to selfantigens would run better, so that theclinical improvement of LES occurred (Nurudhin et al., 2017). 
Besides being able to decrease apoptotic activity through inflammatory inhibition, mesenchymal secretome stem cellalso had anti-apoptotic effects that work directly on the apoptotic pathway. The anti-apoptotic activity of mesenchymal secretome stem cellwas mediated by the blockade of FasL, inhibition of Bax and caspase-3, and increased the levels of Bcl-2 which was an anti-apoptotic factor (Teixeira, 2017; Visozo et al., 2017; Pokrovskaya et al., 2019).

This study concludes thatthere is an effect of mesenchymal secretome stem cell therapy toward the decrease of caspase- 3 expression in pregnant mice with pristaninduced lupus model.

\section{AUTHOR CONTRIBUTION}

Febrian Andhika Adiyana, M. Adrianes Bachnas, Sri Sulistyowati, Nutria Widya Purna Anggraini, and Supriyadi Hari Respati arranged the concept, did mesenchymal secretome stem cell therapy, measured caspase- 3 expression, and drafted the manuscript.

\section{CONFLICT OF INTEREST}

This study did not have any conflicts of interest.

\section{FUNDING AND SPONSORSHIP}

There was no financial support and sponsorship in this study.

\section{ACKNOWLEDGEMENT}

The researchers would like to thank the Dean and the Director of the Faculty of Veterinary Medicine UNAIR who has allowed the researchers to conduct this study.

\section{REFERENCE}

Dos Santos N, Silva RF, Pinto MPL, Da Silva EB, Tasat DR, Amaral A (2017). Active Caspase-3 Expression Levels as Bioindicator of Individual Radiosensitivity. Anais Da Academia Brasileira De Cien- cias. 89(1): 649-659. doi: 10.1590/oo01-3765201720160697.

Drago D, Cossetti C, Iraci N, Gaude E, Musco G, Bachi A, Pluchino S (2013). The stem cell secretome and its role in brain repair. Biochimie. 95:2271-2285. doi: 10.1016/j.biochi.2013.06.020.

Figueroa FE, Carrion F, Villanueva S, Khoury $M$ (2012). Mesenchymal stem cell treatment for autoimmune disease: a critical review. Biol Res. 45: 269-277. doi: 10.4067/So716-97602012000300008.

Harrell CR, Fellabaum C, Jovicic N, Djonov $\mathrm{V}$, Arsenijevic N, Volarevic V (2019). Molecular Mechanisms Responsible for Therapeutic Potential of Mesenchymal Stem Cell-Derived Secretome. Cells. 8(5):467.

Khurana R, Wolf RE (2017). Systemic Lupus Erythematosus and Pregnancy. Retrieved from https://Emedicine.Medscape.Com/Article/335055-Overview.

Lin L, Du L (2018). The Role of Secreted Factors in Stem Cells-mediated Immune Regulation. Cell Immunol. 326: 24-32. doi: 10.1016/j.cellimm.2017.07.010.

Ling N, Lawson E, Von Scheven, E (2018). Adverse Pregnancy Outcomes in Adolescents and Young Women with Systemic Lupus Erythematosus: A National Estimate. Pediatr Rheumatol Online J. 16: 26-31. doi: 10.1186/s12969-018-0242-0.

Nurudhin A, Kertia IN, Adnan ZA (2017). Effect of Secretome Stem Cells on Expression Interleukin 10 and Interleukin 17 in Mice Lupus Model. Bangladesh j med sci. 16(3): 418-22. doi: 10.3329/bjms.v16i3.32862.

Ogishima D, Matsumoto T, Nakamura Y, Yoshida K, Kuwabara Y (2000). Placental Pathology in Systemic Lupus Erythematosus with Antiphospholipid Antibodies. Pathol Int. 50: 224-9. doi: 10.1046/j.1440-1827.2000.01026.x. 
Pokrovskaya LA, Zubareva EV, Nadezhdin SV, Lysenko AS, Litovkina TL (2020). Biological Activity of Mesenchymal Stem Cells Secretome as A Basis for Cell-free Therapeutic Approach. Research Results in Pharmacology. 6(1): 57-68. doi: 10.3897/rrpharmacology.6.49413 .

Prawirohardjo S (2014). Ilmu Kebidanan Sarwono Prawirohardjo. Jakarta. PT. Bina Pustaka Sarwono Prawirohardjo. ISBN: 9789798150258.

Sharp AN, Heazell AEP, Crocker IP, Mor G (2010). Placental apoptosis in health and disease. Am J Reprod Immunol. 64(3):159-169.

Su YJ, Cheng TT, Chen CJ, Chang WN, Tsai NW, Kung CT, Wang HC, et al. (2014). Investigation of the caspase-dependent mitochondrial apoptotic pathway in mononuclear cells of patients with systemic lupus erythematosus. J Transl Med. 12: 303. doi: 10.1186/-s12967014-0303-1.

Teixeira FG, Carvalho MM, Panchalingam KM, Rodrigues AJ, Mendes-Pinheiro B, Anjo S,Manadas B, Behie LA, Sousa N, Salgado AJ (2017). Impact of the secretome of human mesenchymal stem cells on brain structure and animal behavior in a rat model of Parkinson's disease. Stem Cells Transl. Med. 6: 634-646. doi: 10.5966/sctm.2016-0071.

Vizoso FJ, Eiro N, Cid S, Schneider J, PerezFernandez R (2017). Mesenchymal stem cell secretome: Toward cell-free therapeutic strategies in regenerative medicine. Int J Mol Sci. 18: 1852. doi: 10.3390/ijms18091852. 